\title{
STUDIES ON THE RENAL CONCENTRATING MECHANISM. V. EFFECT OF DIURETIC AGENTS *
}

\author{
By WILLIAM Y. W. AU † AND LAWRENCE G. RAISZ $\ddagger$ \\ (From the Medical Research Scrvice, Veterans Administration IIospital and Department of \\ Medicine, State University of Nezv York Upstatc Mcdical Center, \\ Syracuse, $N . Y$.)
}

(Submitted for publication July 20, 1959; accepted April 22, 1960)

Evidence for the site of action of diuretic drugs in man can be derived from observations of their effect on different tubular functions. Previous studies have shown that mercurial diuretic agents have little influence on water diuresis or antidiuresis (1-5) and hydrogen ion secretion $(6,7)$. These observations have been taken to indicate that the predominant action of these mercurial agents is to decrease sodium reabsorption in the proximal tubule. A proximal site of action has also been suggested by stop flow analysis of tubular function during combined mercurial and mannitol diuresis $(8-10)$. The similarity between osmotic and mercurial diuresis has been emphasized $(5,8,11,12)$ but these states have not been compared directly in man. The present study concerns the effects of diuretic drugs on renal concentrating ability in healthy hydropenic young men. The urine was found to be less concentrated during mercurial diuresis when compared with mannitol diuresis at similar urine flows. This difference was greatest when mercurial action was potentiated by the prior administration of ammonium chloride. The data provide evidence that mercurial diuretic agents can act on those portions of the nephron involved in the renal concentrating process, presumably beyond the proximal tubule. Acetazolamide and chlorothiazide, drugs which probably act both distally and proximally $(8,13-$ 15) were also studied. The former was found to decrease concentrating ability, while the latter had little effect.

\section{METHODS}

Experimental procedure. The subjects were 6 paid volunteer medical students, ages 25 to 28 years, who

* Aided in part by a grant from the National Kidney Disease Foundation.

$\dagger$ Life Insurance Medical Research Fund Fellow, 19581959. Present address, USAF Hospital, Maxwell Air Force Base, Ala.

$\ddagger$ Veterans Administration Clinical Investigator. were selected by a "bladder emptying test" for their ability to void small volumes of urine consistently (16). The experiments were begun after 18 hours of water deprivation, at 7 a.m., except in Subject A.G., in whom experiments were begun at 11 a.m. Infusions containing the diuretic agents were administered after 2 to 3 preliminary periods, in which osmotic urine/plasma ratio ranged from 3.0 to 4.6 , and urine flow was less than 0.6 $\mathrm{ml}$ per minute. Urine samples were collected at intervals of 30 minutes and blood samples every 2 hours.

The following experiments were performed in a random sequence for each subject, at intervals of at least 1 week between studies. In all experiments $200 \mathrm{mU}$ of vasopressin ${ }^{1}$ was administered initially. Vasopressin was then added to each infusion to provide $200 \mathrm{mU}$ per hour, except in the repeat experiments with mercaptomerin.

1. Mannitol infusion (all subjects); 5 per cent mannitol in 0.5 per cent $\mathrm{NaCl}$ solution was infused at a rate of $10 \mathrm{ml}$ per minute for 5 hours.

2. Urea infusion ( 3 subjects); 30 per cent urea was infused at 1 to $3 \mathrm{ml}$ per minute for 4 hours.

3. Isotonic sodium chloride infusion ( 3 subjects) ; 0.9 per cent $\mathrm{NaCl}$ solution was infused at 30 to $40 \mathrm{ml}$ per minute for 1 hour, then at $10 \mathrm{ml}$ per minute for the next 3 hours, giving a total volume of about $4 \mathrm{~L}$.

4. Mercaptomerin (all subjects); a solution of mercaptomerin containing $40 \mathrm{mg} \mathrm{Hg}$ in $50 \mathrm{ml}$ of isotonic sodium chloride was injected intravenously, followed by an

TABLE I

Mannitol loading "reference" experiment*

\begin{tabular}{lcccc}
\hline \hline Subject & $\begin{array}{c}\text { No. } \\
\text { of periods }\end{array}$ & $\mathrm{a}$ & $\mathrm{b}$ & $\mathrm{R}$ \\
\hline M.G. & 8 & 0.0874 & 0.3886 & 0.9929 \\
P.M. & 8 & 0.1222 & 0.2839 & 0.9928 \\
A.M. & 7 & 0.0910 & 0.3817 & 0.9961 \\
J.P. & 8 & 0.0940 & 0.3031 & 0.9953 \\
J.S. & 7 & 0.1041 & 0.2442 & 0.9931 \\
A.G. & 8 & 0.1168 & 0.3202 & 0.9948 \\
\hline
\end{tabular}

* The equation, $\frac{1}{U / P-1}=a V+b$, for the mannitol loading "reference" experiment for each subject, is presented in terms of the regression constants $(\mathrm{a}, \mathrm{b})$ and the correlation coefficient (R).

1 A single lot of Pitressin (Parke, Davis) was used which had been shown to cause maximal antidiuresis in hydrated normal man in doses of 25 to $50 \mathrm{mU}$ per hour. 
TABLE II

Summary of individual diuresis experiments*

\begin{tabular}{|c|c|c|c|c|c|c|c|}
\hline \multirow[b]{2}{*}{ Experiment } & \multirow[b]{2}{*}{ Subject } & \multicolumn{2}{|c|}{ Range } & & \multicolumn{3}{|c|}{ Mean } \\
\hline & & $\mathbf{v}$ & $\mathrm{U} / \mathrm{P}$ & & $\Delta U / P$ & $\Delta \mathrm{T}^{\mathrm{c}_{\mathrm{H}}} \mathrm{H}_{\mathbf{2}} \mathrm{O}$ & Cereat \\
\hline \multirow[t]{2}{*}{ Mannitol } & $\begin{array}{l}\text { M.G. } \\
\text { P.M. } \\
\text { A.M. } \\
\text { J.P. } \\
\text { J.S. } \\
\text { A.G. }\end{array}$ & $\begin{array}{c}\mathrm{ml} / \mathrm{min} / 1.73 \mathrm{~m}^{2} \\
1.39-6.35 \\
1.91-7.37 \\
1.41-7.43 \\
1.31-4.74 \\
0.89-5.36 \\
1.60-7.34\end{array}$ & $\begin{array}{l}2.07-3.05 \\
1.85-3.01 \\
1.95-3.01 \\
2.35-3.44 \\
2.27-3.91 \\
1.86-3.06\end{array}$ & & & $m l / m i$ & $\begin{array}{l}m^{2} \\
140 \\
145 \\
105 \\
128 \\
150 \\
131\end{array}$ \\
\hline & & & & Mean & & & 133 \\
\hline \multirow[t]{2}{*}{ Urea } & $\begin{array}{l}\text { M.G. } \\
\text { P.M. } \\
\text { A.M. }\end{array}$ & $\begin{array}{l}1.37-4.17 \\
1.10-4.56 \\
1.52-4.28\end{array}$ & $\begin{array}{l}2.30-3.02 \\
2.21-3.01 \\
2.31-3.30\end{array}$ & & $\begin{array}{r}-0.06 \\
-0.16 \\
0.06\end{array}$ & $\begin{array}{r}-0.19 \\
-0.31 \\
0.10\end{array}$ & $\begin{array}{l}111 \\
166 \\
132\end{array}$ \\
\hline & & & & Mean & -0.05 & -0.13 & 136 \\
\hline \multirow[t]{2}{*}{ Saline } & $\begin{array}{l}\text { M.G. } \\
\text { P.M. } \\
\text { J.P. }\end{array}$ & $\begin{array}{l}1.06-2.58 \\
0.78-2.33 \\
0.96-2.47\end{array}$ & $\begin{array}{l}2.58-3.03 \\
2.49-3.42 \\
2.90-3.72\end{array}$ & & $\begin{array}{r}-0.04 \\
-0.24 \\
0.08\end{array}$ & $\begin{array}{r}-0.06 \\
-0.39 \\
0.10\end{array}$ & $\begin{array}{l}180 \\
145 \\
193\end{array}$ \\
\hline & & & & Mean & -0.07 & -0.12 & 173 \\
\hline \multirow[t]{2}{*}{ Mercaptomerin } & $\begin{array}{l}\text { M.G. } \\
\text { P.M. } \dagger \\
\text { A.M. } \\
\text { J.P. } \\
\text { J.S. } \\
\text { A.G. }\end{array}$ & $\begin{array}{l}2.77-6.98 \\
2.40-6.92 \\
1.20-4.21 \\
1.28-8.97 \\
1.72-5.27 \\
3.87-9.79\end{array}$ & $\begin{array}{l}1.54-2.21 \\
1.46-1.99 \\
1.68-2.85 \\
1.42-2.45 \\
1.64-2.40 \\
1.30-1.73\end{array}$ & & $\begin{array}{l}-0.44 \\
-0.55 \\
-0.53 \\
-0.61 \\
-0.71 \\
-0.41\end{array}$ & $\begin{array}{l}-1.85 \\
-2.34 \\
-1.63 \\
-3.16 \\
-2.76 \\
-2.68\end{array}$ & $\begin{array}{l}142 \\
130 \\
122 \\
125 \\
124 \\
132\end{array}$ \\
\hline & & & & Mean & -0.54 & -2.40 & 129 \\
\hline \multirow[t]{2}{*}{ Meralluride } & $\begin{array}{l}\text { J.P. } \\
\text { J.S. } \\
\text { A.G., } 1 \\
\text { A.G., } 2\end{array}$ & $\begin{array}{l}1.06-6.38 \\
1.52-6.74 \\
1.61-3.29 \\
1.86-4.18\end{array}$ & $\begin{array}{l}1.49-3.00 \\
1.64-2.18 \\
2.49-3.15 \\
2.17-2.74\end{array}$ & & $\begin{array}{r}-0.68 \\
-0.71 \\
0.07 \\
-0.10\end{array}$ & $\begin{array}{r}-2.36 \\
-2.49 \\
0.15 \\
-0.32\end{array}$ & $\begin{array}{l}122 \\
135 \\
154 \\
150\end{array}$ \\
\hline & & & & Mean $\ddagger$ & -0.69 & -2.42 & 128 \\
\hline \multirow[t]{2}{*}{$\mathrm{NH}_{4} \mathrm{Cl}+$ mercaptomerin } & $\begin{array}{l}\text { M.G. } \\
\text { J.P. } \\
\text { J.S. }\end{array}$ & $\begin{array}{l}1.56-8.99 \\
4.47-16.1 \\
1.41-11.9\end{array}$ & $\begin{array}{l}1.28-2.16 \\
1.19-1.33 \\
1.16-2.22\end{array}$ & & $\begin{array}{l}-0.78 \\
-0.64 \\
-0.85\end{array}$ & $\begin{array}{l}-4.08 \\
-5.45 \\
-5.27\end{array}$ & $\begin{array}{l}143 \\
132 \\
103\end{array}$ \\
\hline & & & & Mean & -0.76 & -4.94 & 126 \\
\hline \multirow[t]{2}{*}{ Chlorothiazide } & $\begin{array}{l}\text { M.G. } \\
\text { P.M. } \\
\text { A.M. } \\
\text { J.P. } \\
\text { J.S. } \\
\text { A.G. }\end{array}$ & $\begin{array}{l}2.52-3.34 \\
2.47-5.66 \\
2.36-3.26 \\
1.66-3.87 \\
2.02-2.70 \\
1.91-3.27\end{array}$ & $\begin{array}{l}2.27-2.69 \\
1.81-2.44 \\
2.33-2.76 \\
2.36-2.86 \\
2.48-2.81 \\
2.04-2.77\end{array}$ & & $\begin{array}{l}-0.09 \\
-0.15 \\
-0.02 \\
-0.15 \\
-0.43 \\
-0.13\end{array}$ & $\begin{array}{l}-0.27 \\
-0.60 \\
-0.05 \\
-0.36 \\
-1.05 \\
-0.37\end{array}$ & $\begin{array}{l}139 \\
153 \\
114 \\
131 \\
117 \\
106\end{array}$ \\
\hline & & & & Mean & -0.16 & -0.45 & 127 \\
\hline \multirow[t]{2}{*}{ Acetazolamide } & $\begin{array}{l}\text { J.P. } \\
\text { J.S. } \\
\text { A.G. } \\
\text { P.M. }\end{array}$ & $\begin{array}{l}1.56-2.42 \\
1.56-2.82 \\
1.14-3.58 \\
1.90-4.08\end{array}$ & $\begin{array}{l}2.32-2.74 \\
2.10-2.32 \\
2.14-2.97 \\
1.91-2.50\end{array}$ & & $\begin{array}{l}-0.44 \\
-1.02 \\
-0.23 \\
-0.46\end{array}$ & $\begin{array}{l}-1.01 \\
-1.89 \\
-0.63 \\
-1.19\end{array}$ & $\begin{array}{l}125 \\
142 \\
166 \\
134\end{array}$ \\
\hline & & & & Mean & -0.54 & -1.18 & 142 \\
\hline
\end{tabular}

* Including range of urine flow $(\mathrm{V})$, osmotic $U / P$ ratio $(U / P)$, mean creatinine clearance $\left(C_{\text {creat }}\right)$, and deviation of osmotic $U / P$ ratio $(\Delta U / P)$ and net water reabsorption $\left(\Delta \mathrm{T}^{\mathrm{c}} \mathrm{H}_{2} \mathrm{O}\right)$ from the values predicted from the mannitol loading "reference" experiment.

$\dagger$ Three 60 minute periods only

$\ddagger$ Mean of Subjects J.P. and J.S. only. 
infusion containing $40 \mathrm{mg} \mathrm{Hg}$ in $240 \mathrm{ml}$ of isotonic $\mathrm{NaCl}$ solution at a rate of $1.0 \mathrm{ml}$ per minute. This experiment was repeated in Subjects J.S. and J.P. with the addition of $1,000 \mathrm{mU}$ per hour of vasopressin.

5. Meralluride ( 3 subjects); the procedure and dose were identical with that for mercaptomerin. The experiment was repeated in Subject A.G.
6. Ammonium chloride and mercaptomerin ( 3 subjects) ; the mercaptomerin experiment was repeated after the subjects had received 9 to $12 \mathrm{~g}$ ammonium chloride orally per day for 3 days.

7. Chlorothiazide (all subjects); $0.5 \mathrm{~g}$ of chlorothiazide dissolved in $50 \mathrm{ml}$ isotonic $\mathrm{NaCl}$ solution was injected intravenously followed by an infusion of $0.5 \mathrm{~g}$ chloro-
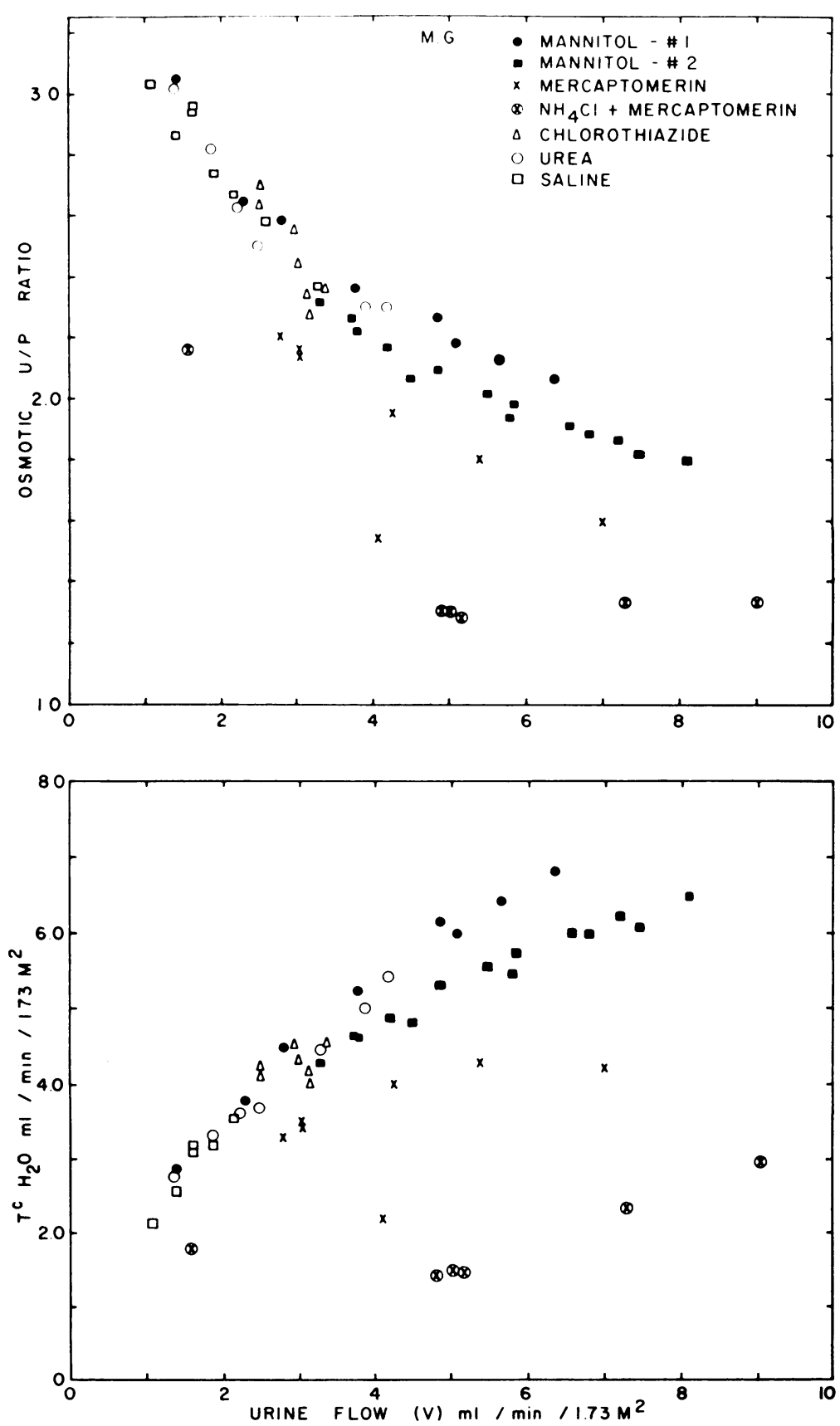

Fig. 1. Concentrating response to various diuretic agents in SubJECT M.G. Mannitol no. 1 indicates the "reference" mannitol loading experiment for this subject. Mannitol no. 2 is a study done one year previously. 

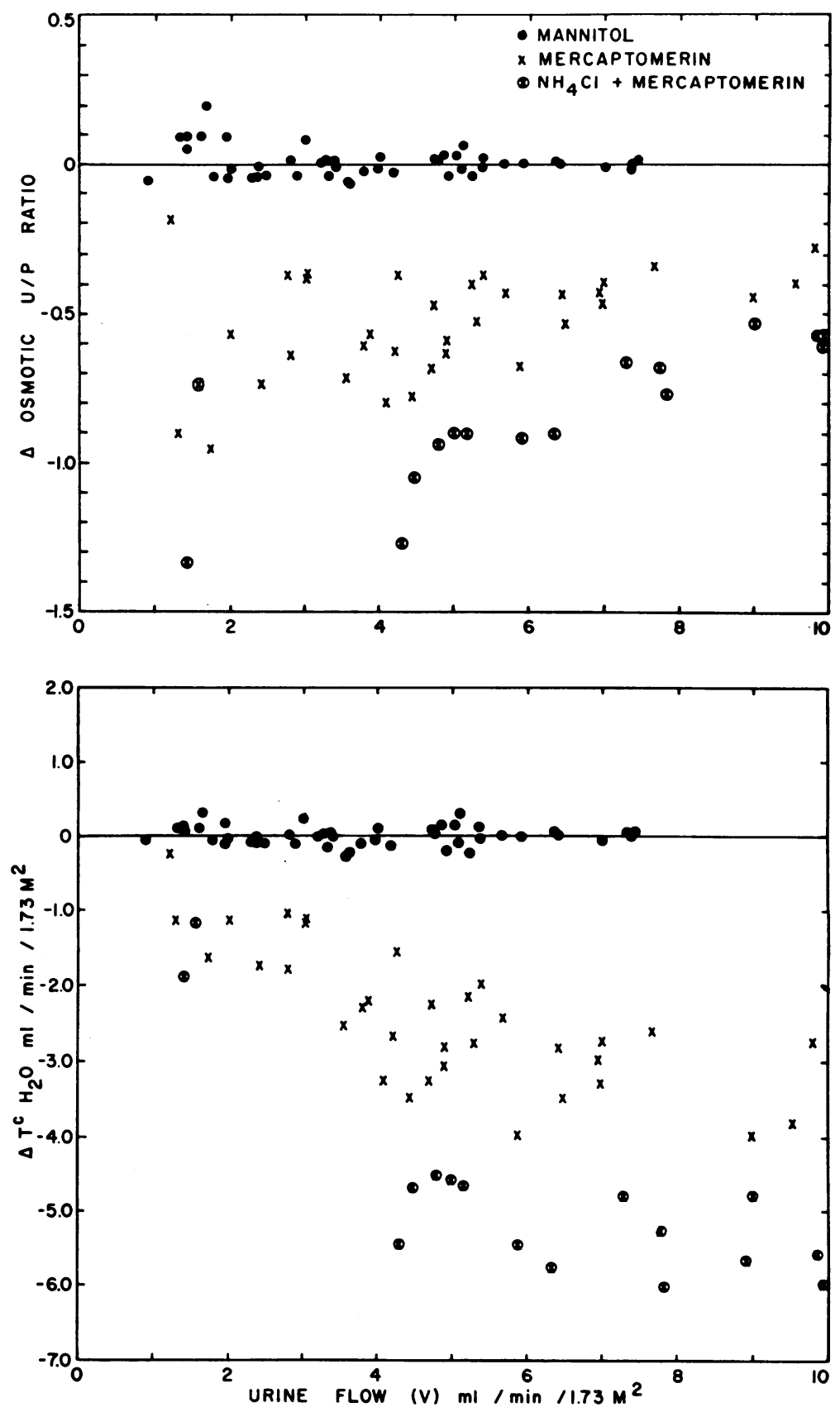

Fig. 2. Deviation of $\Delta$ osmotic U/P Ratio and Net Water ReabsorpTION ( $\Delta \mathrm{T}^{\mathrm{c}}{ }_{\text {H.O }}$ ) FROM VAlues PREDICTED BY THE MANNITOL "REFERENCE" EQUATION (SEE TEXT). Data include periods for mannitol, mercaptomerin, and ammonium chloride-potentiated mercaptomerin diuresis in six subjects.

thiazide in $240 \mathrm{ml}$ of isotonic $\mathrm{NaCl}$ solution at a rate of $1.0 \mathrm{ml}$ per minute.

8. Acetazolamide (4 subjects); the procedure and dose were identical with that for chlorothiazide.

9. Mannitol infusion and mercaptomerin (3 subjects); 10 per cent mannitol was infused at $20 \mathrm{ml}$ per minute until urine flow was 10 to $15 \mathrm{ml}$ per minute for 3 to 4 periods. Mercaptomerin ( $80 \mathrm{mg} \mathrm{Hg}$ ) was then given intravenously and the mannitol infusion continued at 10 $\mathrm{ml}$ per minute for 3.5 hours.

Chemical methods. Chemical methods were those previously described (16). In addition, chloride was determined by the method of Schales and Schales (17). Calculations. Osmoțic urine/plasma (U/P) ratio, 
osmolal clearance ( $\mathrm{C}_{\text {osm }}$ ), and net water reabsorption $\left(\mathrm{T}^{\mathrm{c}}{ }_{\mathrm{H}_{2} \mathrm{O}}\right)$ were calculated as described previously (16, $18,19)$. All data were corrected to $1.73 \mathrm{~m}^{2}$ of body surface area. The relationship between concentrating response and urine flow (V) during osmotic diuresis, when urine flow is less than $20 \mathrm{ml}$ per minute, can be evaluated in terms of an empirical formula described in the preceding paper of this series (19). In the present study, the mannitol loading experiments on each subject were chosen as the "reference" experiment for comparison of the renal concentrating response with other types of diuresis. The regression constants and the correlation coefficient for the hyperbolic equation, $\frac{1}{U / P-1}=a V+b$, where $\mathrm{U} / \mathrm{P}$ represents the osmotic $\mathrm{U} / \mathrm{P}$ ratio, $\mathrm{V}$ is urine flow, and $\mathrm{a}$ and $\mathrm{b}$ are constants, were calculated for each mannitol loading "reference" experiment by the method of least squares [(20) Table I]. Using this equation, it was possible to calculate predicted values for osmotic $\mathrm{U} / \mathrm{P}$ ratio and $\mathrm{T}^{\mathrm{c}}{ }_{\mathrm{H}_{2} \mathrm{O}},\left[\mathrm{T}^{\mathrm{c}}{ }_{\mathrm{H}_{2} \mathrm{O}}=(\mathrm{U} / \mathrm{P}-1) \times \mathrm{V}\right]$ for any given rate of urine flow. Differences in concentrating response between the mannitol experiment and other forms of diuresis in each subject could then be quantitated by comparing observed osmotic $U / P$ ratio and $T^{c}{ }_{H_{2} O}$ values

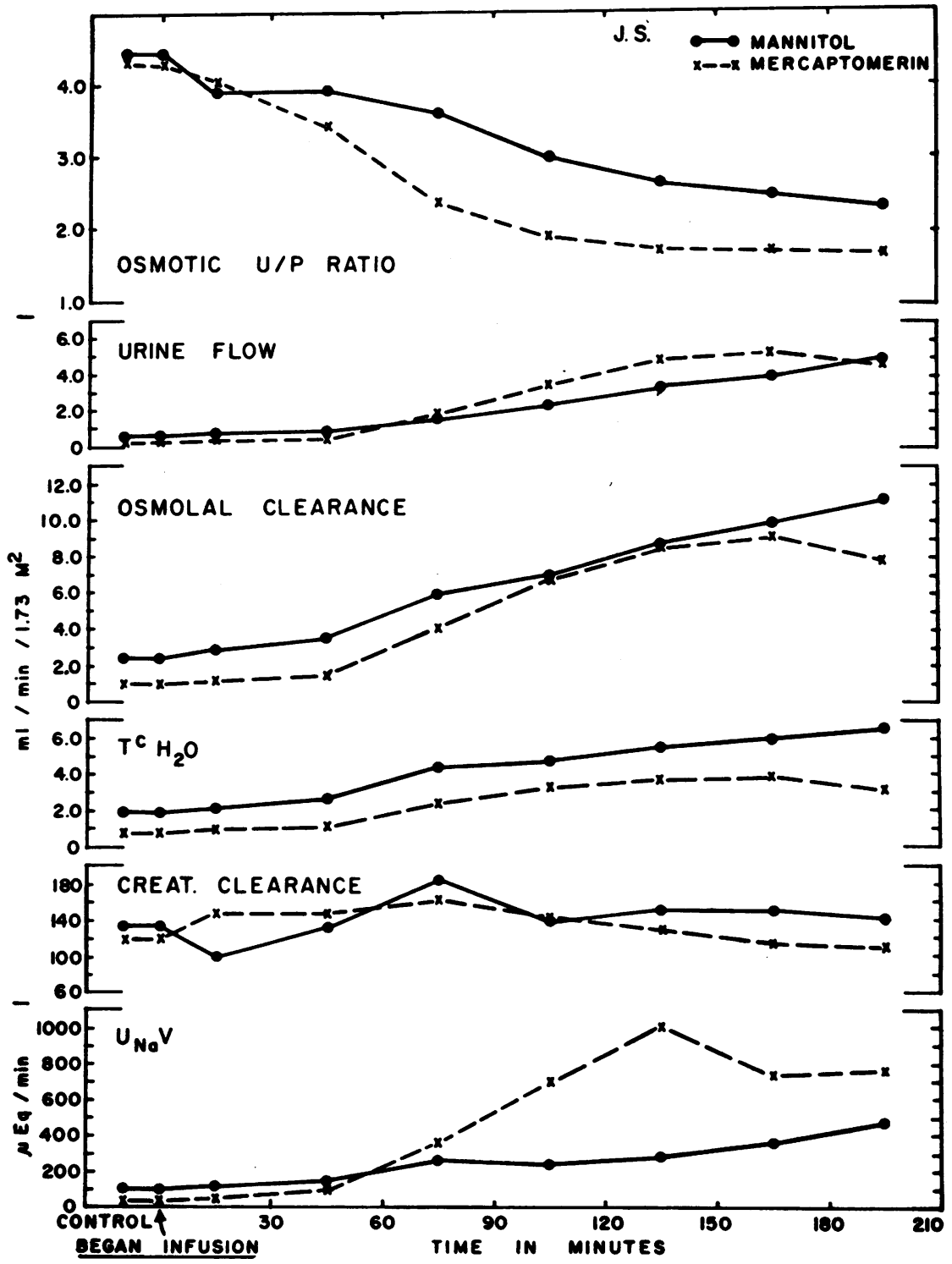

Fig. 3. COMPARISON OF INDIVIDUAL EXPERIMENTS WITH MANNITOL LOADING AND MERCAPTOMERIN DIURESIS IN SUbJect J.S. Osmotic U/P ratio, urine flow, osmolal clearance, net water reabsorption $\left(\mathrm{T}^{\mathrm{c}} \mathrm{H}_{2} \mathrm{O}\right)$, creatinine clearance, and sodium excretion $\left(\mathrm{U}_{\mathrm{Na}} \mathrm{V}\right)$ are given for individual periods. 
TABLE III

Effect of mercaptomerin during hypertonic mannitol loading*

\begin{tabular}{|c|c|c|c|c|c|c|}
\hline Subject & Time & $\mathrm{v}$ & $\mathrm{U} / \mathrm{P}$ & $\mathrm{T}^{\mathrm{e}_{\mathrm{H}} \mathrm{O}}$ & $\mathrm{U}_{\mathrm{NaV}} \mathrm{V}$ & $\frac{U_{\mathrm{Na}}}{U_{\text {osm }}} \times 100$ \\
\hline J.P. & $\begin{array}{c}\min \\
-40-0 \\
70-110 \\
150-180\end{array}$ & $\begin{array}{c}m l / m i n / 1.73 \mathrm{~m}^{2} \\
14.0 \\
19.2 \\
20.6\end{array}$ & $\begin{array}{l}1.50 \\
1.32 \\
1.34\end{array}$ & $\begin{array}{c}\mathrm{ml} / \mathrm{min} / 1.73 \mathrm{~m}^{2} \\
7.0 \\
6.2 \\
6.9\end{array}$ & $\begin{array}{c}\mu E q / \min / 1.73 \mathrm{~m}^{2} \\
577 \\
1,127 \\
1,144\end{array}$ & $\begin{array}{r}9 \\
15 \\
14\end{array}$ \\
\hline J.S. & $\begin{array}{l}-40-0 \\
70-110 \\
150-170\end{array}$ & $\begin{array}{l}11.3 \\
12.8 \\
17.4\end{array}$ & $\begin{array}{l}1.57 \\
1.46 \\
1.36\end{array}$ & $\begin{array}{l}6.4 \\
5.8 \\
6.2\end{array}$ & $\begin{array}{r}370 \\
705 \\
1,234\end{array}$ & $\begin{array}{r}7 \\
12 \\
17\end{array}$ \\
\hline A.G. & $\begin{array}{l}-45-0 \\
75-120 \\
150-195\end{array}$ & $\begin{array}{l}10.8 \\
21.7 \\
21.3\end{array}$ & $\begin{array}{l}1.48 \\
1.18 \\
1.26\end{array}$ & $\begin{array}{l}5.2 \\
3.8 \\
5.6\end{array}$ & $\begin{array}{r}515 \\
1,741 \\
1,515\end{array}$ & $\begin{array}{l}11 \\
23 \\
19\end{array}$ \\
\hline
\end{tabular}

${ }^{*}$ Mean urine flow $(\mathrm{V})$, osmotic $\mathrm{U} / \mathrm{P}$ ratio $(\mathrm{U} / \mathrm{P})$, net water reabsorption $\left(\mathrm{T}^{\mathrm{c}}{ }_{\mathrm{H}_{2} \mathrm{O}} \mathrm{O}\right)$, sodium excretion $\left(\mathrm{U}_{\mathrm{Na}} \mathrm{V}\right)$ and percentage of urine osmolality accounted for by sodium $\left(\frac{U_{\mathrm{Na}}}{U_{\text {osm }}} \times 100\right)$ are given for periods before, 1 to 2 hours after, and 2.5 to 3 hours after mercaptomerin administration.

with those predicted for the same rate of urine flow by the equation for the mannitol "reference" experiment. The differences between observed and predicted values are termed $\Delta \mathrm{U} / \mathrm{P}$ and $\Delta \mathrm{T}^{\mathrm{c}} \mathrm{H}_{\mathbf{2}}$. In 3 subjects, M.G., P.M. and A.M., data from previous mannitol loading experiments (19) over the range of 1 to $20 \mathrm{ml}$ per minute urine flow showed good agreement with the mannitol "reference" experiment, so that calculated $\Delta U / P$ values for individual collection periods were always between +0.15 and -0.30 .

\section{RESULTS}

The renal concentrating response during different types of diuresis is illustrated for one subject in Figure 1. The mean values for $\Delta \mathrm{U} / \mathrm{P}$ and $\Delta \mathrm{T}^{\mathbf{c}} \mathbf{H}_{\mathbf{2}} \mathbf{O}$ for each experiment are given in Table II. The concentrating response to urea and saline diuresis showed no consistent deviation from that observed with mannitol loading, although in individual periods $\Delta \mathrm{U} / \mathrm{P}$ ranged from +0.38 to -0.50 and $\Delta \mathrm{T}^{\mathrm{c}} \mathrm{H}_{2} \mathrm{O}$ from +0.58 to $-0.73 \mathrm{ml}$ per minute.

A consistently lower osmotic $\mathrm{U} / \mathrm{P}$ ratio and smaller $\mathrm{T}^{\mathbf{c}}{ }_{\mathrm{H}_{2} \mathrm{O}}$ was observed during mercaptomerin diuresis as compared with osmotic diuresis at similar urine flows (Figure 2, Table II). Mean $\Delta \mathrm{U} / \mathrm{P}$ for all six subjects was -0.54 (individual periods ranged from -0.19 to -0.96$)$ and $\Delta \mathrm{T}^{\mathbf{c}}{ }_{\mathrm{H}_{2} \mathrm{O}}$ was $-2.40 \mathrm{ml}$ per minute (individual periods ranged from -0.24 to $-4.00 \mathrm{ml}$ per minute). The contrast between mannitol loading and mercaptomerin experiments in one subject, J.S., is shown in Figure 3. Depression of osmotic U/P ratio appeared early in mercurial diuresis and pre- ceded the peak natriuretic response. An even greater change in concentrating response is observed during mercaptomerin diuresis which has been potentiated by prior administration of ammonium chloride (Table II). Although larger peak urine flows were also achieved, greater deviations in the concentrating response were seen even at lower rates of urine flow (Figures 1,2). When the dose of vasopressin was increased to $1,000 \mathrm{mU}$ per hour in repeat mercaptomerin experiments on J.S. and J.P., the depression of concentrating ability was as great as that observed in the original mercaptomerin experiment (mean $\Delta \mathrm{U} / \mathrm{P}$ values were -0.65 and -0.69 , respectively) .

The concentrating response during meralluride diuresis was the same as that observed for mercaptomerin in Subjects J.P. and J.S. In Subject A.G. there was no impairment of concentrating ability in the first experiment in which meralluride caused only a small increase in urine flow and sodium excretion. In the second meralluride experiment, Subject A.G. showed a greater diuresis but only a slight decrease in concentrating ability.

When mercaptomerin was administered during a hypertonic mannitol infusion there was a small decrease in $\mathrm{T}^{\mathrm{c}}{ }_{\mathrm{H}_{2} \mathrm{O}}$ despite a further increase in urine flow; 2.5 to 3 hours after mercaptomerin administration $\mathrm{T}_{\mathrm{H}_{2} \mathrm{O}} \mathrm{O}_{\text {ad }}$ returned toward control values, although urine flow and sodium excretion remained high (Table III).

Chlorothiazide and acetazolamide yielded considerably smaller increases in urine flow than did 
TABLE II

Effect of diuretic agents on urinary composition*

\begin{tabular}{|c|c|c|c|c|c|c|c|c|c|}
\hline Diuretic agent & $\begin{array}{c}\text { No. of } \\
\text { experiments }\end{array}$ & $\mathrm{V}$ & $\mathrm{U}_{0 \times m \mathrm{~m}} \mathrm{~V}$ & $\mathrm{UNaV}_{\mathrm{Na}}$ & $\mathrm{UKV}_{\mathrm{K}}$ & $\mathrm{Uc}_{\mathrm{C}} \mathrm{V}$ & Uurea $V$ & $\frac{\mathrm{U}_{\mathrm{a}}}{\mathrm{U}_{\mathrm{osm}}} \times 100$ & $\frac{\mathrm{U}_{\mathrm{K}}}{\mathrm{U}_{\mathrm{osm}}} \times 100$ \\
\hline & & $\mathrm{ml} / \mathrm{min}$ & $\mu O s m / \min$ & & $\mu E q / \min$ & & umoles $/ \mathrm{min}$ & & \\
\hline Mannitol & 6 & 5.98 & 3,612 & 470 & 80 & 435 & 333 & 13.0 & 2.2 \\
\hline Isotonic $\mathrm{NaCl}$ & 3 & 2.36 & 1,838 & 582 & 116 & 614 & 393 & 31.7 & 6.3 \\
\hline Urea & 3 & 4.09 & 2,898 & 420 & 103 & 380 & 1,925 & 14.5 & 3.6 \\
\hline Mercaptomerin & 6 & 6.59 & 2,903 & 1,155 & 68 & 1,170 & 317 & 39.8 & 2.3 \\
\hline $\mathrm{NH} C \mathrm{Cl}+$ mercaptomeri & 3 & 11.0 & 3,812 & 1,360 & 112 & 1,581 & 266 & 35.6 & 2.8 \\
\hline Meralluride $\dagger$ & 2 & 6.18 & 2,882 & 1,192 & 34 & 1,035 & 289 & 41.4 & 1.2 \\
\hline Chlorothiazide & 6 & 3.35 & 2,228 & 777 & 187 & 576 & 342 & 34.5 & 8.4 \\
\hline Acetazolamide & 4 & 2.82 & 1,776 & 568 & 230 & 244 & 320 & 31.6 & 13.1 \\
\hline
\end{tabular}

* Urine flow $(\mathrm{V})$, total solute $\left(\mathrm{U}_{\mathrm{osm}} \mathrm{V}\right)$, sodium $\left(\mathrm{U}_{\mathrm{Na}} \mathrm{V}\right)$, potassium $\left(\mathrm{U}_{\mathrm{K}} \mathrm{V}\right)$, chloride $\left(\mathrm{U}_{\mathrm{Cl}} \mathrm{V}\right)$, and urea $\left(\mathrm{U}_{\mathrm{urea}} \mathrm{V}\right)$ excretion, and percentage of total solutes accounted for by $\mathrm{Na}\left(\frac{\mathrm{U}_{\mathrm{Na}}}{\mathrm{U}_{\text {osm }}} \times 100\right)$ and $\mathrm{K}\left(\frac{\mathrm{U}_{\mathrm{K}}}{\mathrm{U}_{\text {osm }}} \times 100\right)$ are given for the maximal hourly urine flow.

† Subjects J.P. and J.S. only.

mercaptomerin. During chlorothiazide diuresis concentrating ability was only slightly less than that observed with mannitol loading, except in Subject J.S. who showed a definite decrease. Acetazolamide caused a distinct decrease in concentrating ability, and in Subject J.S. this decrease was relatively greater than that observed with mercaptomerin.

Endogenous creatinine clearance values were little affected by any of the agents studied, except for an increase with saline loading. Transient depressions of creatinine clearance were not encountered with any of the agents used in these experiments.

The patterns of urinary electrolyte composition observed during the peak response to the various agents are shown in Table IV. Mercurial diuretic agents primarily increased sodium and chloride excretion, while chlorothiazide and acetazolamide increased potassium as well as sodium excretion and caused less increase in chloride excretion. The resultant increase in undetermined anion was presumably due to increased bicarbonate excretion. This difference was greatest with acetazolamide diuresis. There were no consistent changes in plasma composition with any of the agents used except for a decrease in plasma bicarbonate concentration to 17 mmoles per $\mathrm{L}$ after three days of ammonium chloride administration.

\section{DISCUSSION}

The urine is less concentrated during mercurial diuresis than it is during osmotic diuresis at com- parable urine flows in the same subjects. This apparent impairment of the ability of the kidney to elaborate a concentrated urine could be due to inhibition of antidiuretic hormone, to a direct effect on water transport, or to inhibition of a moiety of sodium reabsorption which is essential to the concentrating process. Inhibition of antidiuretic hormone could decrease concentrating ability by altering water reabsorption (21) or by altering sodium reabsorption in the loop of Henle (22) if antidiuretic hormone increases sodium reabsorption at this site as it does in the short-circuited toad bladder (23). A recent study has suggested that antidiuretic hormone might act on the renal tubule by forming disulfide linkages with proteins in the cell membrane (24). Since mercurial diuretic compounds are known to bind available sulfhydryl groups (25) these agents might compete for available binding sites. Competitive inhibition of antidiuretic hormone action could not be demonstrated in the present study. however, since a fivefold increase in the dose of exogenous vasopressin did not alter the mercurial effect on concentrating ability. Mercurial diuretic agents might act on concentrating ability by directly inhibiting water transport. Since net water reabsorption at the concentrating site is probably passive in response to an osmotic gradient $(21,22,26)$, such an inhibition should then be due to decreased membrane permeability. However, Garby and Linderholm (27) have shown that mersalyl has no effect on the permeability of frog skin to heavy water, but it does cause a de- 
crease in active sodium transport. Could impairment of concentrating ability be ascribed to the direct action of organomercurial agents on sodium transport in the renal tubules? It has been postulated on the basis of stop flow analysis that mercurial diuretic agents act by inhibiting active (9) or passive (10) sodium reabsorption in the proximal tubule. Such an effect would not explain impairment of concentrating ability relative to that observed during osmotic diuresis since the latter also decreases proximal sodium reabsorption (28).

Recent evidence indicates that the renal concentrating process operates by means of a countercurrent multiplier system which is initiated by active sodium transport in the loop of Henle $(21,22$, $26,29,30)$. This produces a hypertonic renal medullary interstitial fluid, which results in passive reabsorption of water from the collecting ducts. If this hypothesis is correct, it then appears likely that mercurial diuretic agents impair concentrating ability by inhibiting sodium transport in the loop of Henle. The localization of mercurial diuretic action to this site is further suggested by histochemical data which show that the number of available sulfhydryl binding sites in the ascending portion of the loop of Henle is decreased after the administration of mersalyl (25).

The greater impairment of concentrating ability observed when mercurial diuretics were given during ammonium chloride acidosis is not unexpected if acidosis potentiates mercurial inhibition of sodium transport at the concentrating site. Ammonium chloride acidosis itself did not impair renal concentrating ability in preliminary periods in these subjects or in three additional subjects studied before and after the administration of ammonium chloride for three days. Moreover, intravenous acid loading in hydropenic dogs does not appear to affect renal concentrating ability (31, 32).

Previous studies assigning mercurial action to the proximal tubule have cited the apparent lack of effect of these drugs on net water reabsorption during antidiuresis $(3,5)$ and on free water clearance during maximal water diuresis $(1,2)$. In a more recent study, free water clearance was found to increase during combined mercurial and water diuresis (33) but this could still be consistent with a proximal site of action. Although direct comparison of osmotic and mercurial diuresis was not made, in one of the available studies in man (5) concentrating ability may have been depressed during mercurial diuresis, since values of $\mathrm{T}^{\mathrm{c}_{\mathrm{H}_{2} \mathrm{O}}}$ were generally less than $4 \mathrm{ml}$ per minute when urine flow was $15 \mathrm{ml}$ per minute. In hydropenic dogs, Brodsky and Graubarth (11) found no difference in the relationship between osmotic load and urine flow when they compared meralluride and mannitol diuresis. The effects of meralluride and mercaptomerin on the concentrating mechanism were different in one subject of the present study, but identical in two others.

In the present study there was little alteration in the rate of net water reabsorption when mercurial diuresis was superimposed on a mannitol diuresis at high urine flows. Interpretation of these data is difficult since $\mathrm{T}_{\mathrm{H}_{2} \mathrm{O}}$ can vary with different types of osmotic diuresis at high urine flows (19). If, as Malvin and Wilde (34) have recently suggested, the countercurrent gradient is "washed out" during massive osmotic diuresis then, under these circumstances, the action of inhibitory drugs on the concentrating mechanism could be less apparent.

Impairment of concentrating ability during acetazolamide diuresis suggests that carbonic anhydrase inhibition may affect sodium transport in the loop of Henle. The increased bicarbonate ion in the tubule does not appear to be a factor since sodium bicarbonate infusions in dogs (30) and in one of our subjects (unpublished observations) did not impair concentrating ability. Chlorothiazide, which in addition to inhibiting carbonic anhydrase to a lesser extent appears to act chiefly on sodium chloride reabsorption $(8,13,35)$, caused little impairment of concentrating ability. Others have found no impairment of net water reabsorption during mannitol diuresis in subjects given chlorothiazide $(33,36)$. These results with chlorothiazide would indicate that the difference between mannitol and mercurial diuresis is not due to the fact that sodium chloride is the predominant urinary solute during drug-induced diuresis. Actually, sodium chloride diuresis produces a somewhat more concentrated urine than does mannitol diuresis in hydropenic rats (22).

Impairment of concentrating ability during mercurial diuresis has been quite transient in the subjects of the present study. Further studies are 
required to determine whether this effect is similarly transient in patients requiring diuretic therapy. The fact that the urine is less concentrated during mercurial diuresis may actually represent an advantage to the patient with edema, who must excrete an excess of isotonic extracellular fluid, in the presence of maximal antidiuretic hormone action.

\section{SUMMARY}

The effect of osmotic (mannitol, urea, saline), mercurial, ammonium chloride-potentiated mercurial, chlorothiazide, and acetazolamide diuresis on renal concentrating ability was determined in six hydropenic young men. There was no consistent difference between the response of the concentrating mechanism to mannitol, urea, and saline diuresis at low rates of urine flow. A marked decrease in concentrating ability was seen during mercaptomerin diuresis as compared with mannitol diuresis at the same urine flows. Meralluride diuresis was associated with a similar decrease in two of three subjects studied. When mercaptomerin action was potentiated by prior administration of ammonium chloride, there was greater apparent impairment of concentrating ability than with mercaptomerin alone. This impairment indicates that mercurial diuretic agents act at the renal concentrating site as well as on the proximal tubule. Acetazolamide was also found to cause a decrease in renal concentrating ability while chlorothiazide had little effect.

\section{ACKNOWLEDGMENT}

The authors wish to acknowledge the able technical assistance of Miss Patricia Maley, Mrs. Kathleen Brenon and Miss Emma Rees, and wish to thank the medical students who served as subjects in these experiments.

\section{REFERENCES}

1. Wesson, L. G., Jr., and Anslow, W. P., Jr. Effect of osmotic and mercurial diuresis on simultaneous water diuresis. Amer. J. Physiol. 1952, 170, 255.

2. Ladd, M. Renal excretion of sodium and water in man as affected by prehydration, saline infusion, Pitressin and Thiomerin. J. appl. Physiol. 1952, 4, 602 .

3. Welt, L. G., Goodyer, A. V. N., Darragh, J. H., Abele, W. A., and Meroney, W. H. Site of saluretic action of an organic mercurial compound. J. appl. Physiol. 1953, 6, 134.
4. Capps, J. N., Wiggins, W. S., Axelrod, D. R., and Pitts, R. F. The effect of mercurial diuretics on the excretion of water. Circulation 1952, 6, 82.

5. Grossman, J., Weston, R. E., Borun, E. R., and Leiter, L. Factors influencing the course of mercurial diuresis during Pitressin infusion in normal subjects. J. clin. Invest. 1955, 34, 1611.

6. Blumgart, H. L., Gilligan, D. R., Levy, R. D., Brown, M. G., and Volk, M. C. Action of diuretics in normal persons. Arch. intern. Med. 1934, 54, 40.

7. Weston, R. E., Grossman, J., and Leiter, L. The effect of mercurial diuretics on renal ammonia and titratable acidity production in acidotic human subjects with reference to site of diuretic action. J. clin. Invest. 1951, 30, 1262.

8. Pitts, R. F. Some reflections on mechanisms of action of diuretics. Amer. J. Med. 1958, 24, 745.

9. Kessler, R. H., Hierholzer, K., Gurd, R. S., and Pitts, R. F. Localization of diuretic action of chlormerodrin in the nephron of the dog. Amer. J. Physiol. 1958, 194, 540.

10. Vander, A. J., Malvin, R. L., Wilde, W. S., and Sullivan, L. P. Localization of the site of action of mercurial diuretics by stop-flow analysis. Amer. J. Physiol. 1958, 195, 558.

11. Brodsky, W. A., and Graubarth, H. N. Mechanism of mercurial diuresis in hydropenic dogs. Amer. J. Physiol. 1953, 172, 67.

12. Spritz, N., Frimpter, G. W., Braveman, W. S., and Rubin, A. L. Osmole and water excretion in mercurial diuresis in congestive heart failure. Circulation 1959, 19, 600.

13. Beyer, K. H. The mechanism of action of chlorothiazide. Ann. N. Y. Acad. Sci. 1958, 71, 363.

14. Pitts, R. F., Krück, F., Lozano, R., Taylor, D. W., Heidenreich, O. P., and Kessler, R. H. Studies on the mechanism of diuretic action of chlorothiazide. J. Pharmacol. exp. Ther. 1958, 123, 89.

15. Vander, A. J., Malvin, R. L., Wilde, W. S., and Sullivan, L. P. Localization of the site of action of chlorothiazide by stop-flow analysis. J. Pharmacol. exp. Ther. 1959, 125, 19.

16. Raisz, L. G., and Scheer, R. L. Studies on the renal concentrating mechanism. II. Effect of small acute changes in solute excretion. J. clin. Invest. 1959, 38, 1.

17. Schales, O., and Schales, S. S. A simple and accurate method for the determination of chloride in biological fluids. J. biol. Chem. 1941, 140, 879.

18. Raisz, L. G., Au, W. Y. W., and Scheer, R. L. Studies on the renal concentrating mechanism. III. Effect of heavy exercise. J. clin. Invest. 1959, 38, 8.

19. Raisz, L. G., Au, W. Y. W., and Scheer, R. L. Studies on the renal concentrating mechanism. IV. Osmotic diuresis. J. clin. Invest. 1959, 38, 1725.

20. Snedecor, G. W. Statistical Methods, 5th ed. Ames, Iowa, Iowa State College Press, 1956, p. 534. 
21. Wirz, H. The localization of antidiuretic action in the mammalian kidney in The Neurohypophysis, H. Heller, Ed. Proc. Eighth Symp. Colston Research Soc. New York, Academic Press, 1957, pp. 157 ff.

22. Gottschalk, C. W., and Mylle, M. Micropuncture study of the mammalian urinary concentrating mechanism: Evidence for the countercurrent hypothesis. Amer. J. Physiol. 1959, 196, 927.

23. Leaf, A., Anderson, J., and Page, L. B. Active sodium transport by the isolated toad bladder. $\mathrm{J}$. gen. Physiol. 1958, 41, 657.

24. Schwartz, I. L., Fong, C. T. O., Popenoe, E. A., Silver, L., and Schoessler, M. A. Evidence for a covalent attachment of the antidiuretic hormone to its receptor site in the kidney (abstract). J. clin. Invest. 1959, 38, 1041.

25. Cafruny, E. J., Farah, A., and Di Stefano, H. S. Effects of the mercurial diuretic mersalyl on protein-bound sulfhydryl groups in the cytoplasma of rat kidney cells. J. Pharmacol. exp. Ther. 1955, 115, 390.

26. Berliner, R. W., Levinsky, N. G., Davidson, D. G., and Eden, $M$. Dilution and concentration of the urine and the action of antidiuretic hormone. Amer. J. Med. 1958, 24, 730.

27. Garby, L., and Linderholm, H. The permeability of frog skin to heavy water and to ions, with special reference to the effect of some diuretics. Acta physiol. scand. 1953, 28, 336.

28. Smith, H. W. The Kidney: Structure and Function in Health and Disease. New York, Oxford Univ. Press, 1951, p. 310.

29. Lamdin, E. Mechanisms of urinary concentration and dilution. A. M. A. Arch. intern. Med. 1959, 103, 644.

30. Smith, H. W. The fate of sodium and water in the renal tubules. Bull. N. Y. Acad. Med. 1959, 35, 293.

31. Brodsky, W. A. Effect of acidosis and alkalosis on excretion of water and solutes during periods of hydropenia and of overhydration in dogs. Amer. J. Physiol. 1955, 180, 183.

32. Brodsky, W. A. Regulation of urine flow and solute excretion during acute acidosis induced by loading with strong mineral acids in hydropenic dogs. Amer. J. Physiol. 1955, 181, 616.

33. Heinemann, H. O., Demartini, F. E., and Laragh, J. $H$. The effect of chlorothiazide on renal excretion of electrolytes and free water. Amer. J. Med. 1959, 26, 853.

34. Malvin, R. L., and Wilde, W. S. Washout of the renal countercurrent $\mathrm{Na}$ gradient by osmotic diuresis. Amer. J. Physiol. 1959, 197, 177.

35. Kessler, R. H., Hierholzer, K., Gurd, R. S., and Pitts, R. F. Localization of action of chlorothiazide in the nephron of the dog. Amer. J. Physiol. 1959, 196, 1346.

36. Corcoran, A. C., Macleod, C., Dustan, H. P., and Page, I. H. Effects of chlorothiazide on specific renal functions in hypertension. Circulation 1959, 19, 355. 